ISSN 1411 - 0067 Jurnal Ilmu-Ilmu Pertanian Indonesia. Volume 9, No. 1, 2007, Hlm. 6 - 11

\title{
HUBUNGAN ANTARA KANDUNGAN LIGNIN KULIT BENIH DENGAN SIFAT-SIFAT KHUSUS KULIT BENIH KACANG HIJAU
}

\author{
RELATIONSHIP BETWEEN SEED COAT LIGNIN CONTENT AND SEED COAT \\ CHARACTERISTICS IN MUNG BEAN
}

\author{
Marwanto \\ Jurusan Budidadaya Pertanian Fakultas Pertanian Universitas Bengkulu \\ Jalan Raya Kandang Limun Bengkulu 38371A \\ marwanto@yahoo.com
}

\begin{abstract}
Lignin content in seed coat may have a direct effect on seed coat characteristics of mung bean genotypes (Vigna radiata). This research was designed to study the variation of seed coat lignin content among mung bean genotypes and its relationship to permeability, seed electrolyte conductivity and hard seed. Seeds of eleven mung bean genotypes were grown in research plots at Agriculture Faculty, Bengkulu University on February 2002 and hand harvested at R8 maturation stage. The plots were arranged in a randomized complete block design having three replications. Genotypic differences were evident for seed coat lignin content, seed coat permeability, seed electrolyte conductivity and hard seed. The seed coat lignin content contributed to variability in permeability, seed electrolyte conductivity and hard seed and closely related with permeability $(\mathrm{r}=$ $\left.0.75^{*}\right)$, with seed electrolyte conductivity $\left(\mathrm{r}=-0.93^{* *}\right)$ and with hard seed $\left(\mathrm{r}=-0.71^{*}\right)$. Overall, seed coat lignin content appears to have determining effects on seed coat characteristics.
\end{abstract}

Key words: mung bean, seed coat, electrolyte conductivity, permeability, lignin, hard seed

\begin{abstract}
ABSTRAK
Kandungan lignin dalam kulit benih mungkin berhubungan langsung dengan sifat khusus kulit benih kacang hijau (Vigna radiata). Penelitian ini bertujuan mempelajari keragaman kandungan lignin kulit benih kacang hijau dan hubungannya dengan permeabilitas, daya hantar listrik (DHL) dan benih keras. Sebanyak 11 genotipe kacang hijau ditanam di lahan percobaan Fakultas Pertanian Universitas Bengkulu pada bulan Pebruari 2002 dan dipanen pada fase R8 (matang penuh). Unit percobaan ditata dalam rancangan acak kelompok lengkap dengan tiga ulangan. Hasilnya menunjukkan bahwa terdapat perbedaan kandungan lignin dalam kulit benih, permeabilitas, DHL dan benih keras antar genotipe. Kandungan lignin dalam kulit benih disimpulkan sebagai penyebab beragamnya permeabilitas, DHL dan benih keras dan berhubungan erat dengan permeabilitas $\left(r=0.75^{*}\right)$, dengan DHL $(r=-0.93 * *)$ dan dengan benih keras $(r=-0.71 *)$. Akhirnya, kandungan lignin dalam kulit benih nampaknya berperan serta sebagai penentu terhadap sifat khusus kulit benih.
\end{abstract}

Kata kunci: kacang hijau, kulit benih, daya hantar listrik, permeabilitas, lignin, benih keras

\section{PENDAHULUAN}

Di daerah tropis cukup sulit untuk memproduksi benih dengan mutu tinggi karena benih tersebut mengalami penurunan daya tumbuhnya sebelum dipanen. Menurut Keigly and Mullen (1986) kelembaban dan suhu udara yang mendera benih sewaktu benih masih berada di lapang berperan sebagai faktor utama terhadap rendahnya daya tumbuh benih tersebut. Deraan oleh kelembaban dan suhu udara yang dapat menurunkan mutu benih untuk selanjutnya disebut deraan cuaca (weathering). Penurunan mutu benih oleh deraan cuaca tidak dapat dihindari. Oleh karena itu, benih dengan mutu tinggi sewaktu dipanen hanya dapat diperoleh bila benih tersebut memiliki sifat resisten terhadap deraan cuaca tersebut. Hasil penelitian pada benih kedelai 
sebelumnya menunjukkan bahwa antar genotipe memiliki derajat resistensi yang berbeda terhadap deraan cuaca (Dassou and Kueneman, 1984; Marwanto, 2003 a, c). Lebih lanjut beberapa peneliti mengemukakan bahwa benih kedelai yang resisten terhadap deraan cuaca umumnya memiliki permeabilitas kulit benih yang rendah (low seed coat permeability) (Marwanto, 2003c; Dassou and Kueneman, 1984) ataupun kulit benih yang keras (hard seed coat) (Dassou and Kueneman, 1984; Kuo, 1989). Menurut Halloin (1983) kulit benih sebagai faktor penentu permeabiltas berfungsi (1) sebagai penghalang mekanis (mechanical barrier) sewaktu benih menyerap air (moisture) dari udara sekelilingnya yang lembab akibat sifatnya yang higroskopis, dan (2) sebagai penghalang (barrier) terhadap merembesnya elektrolit (electrolyte leakage) dan keluarnya senyawa-senyawa dari dalam benih seperti gula melalui kulitnya sewaktu benih berada dalam udara yang lembab maupun media basah lainnya. Menurut Tavares et al. (1987) pada benih dengan permeabilitas rendah akan terjadi penyerapan air (imbibisi) yang lambat ataupun sebaliknya. Sedang pada benih keras kulit benihnya bersifat impermeabel terhadap air (water impermeability of seed coat) (Hartwig and Potts, 1987). Menurut McDougall (1996) kapasitas dan kecepatan penyerapan air maupun banyaknya rembesan isi sel (electrolyte leakage) melalui kulit benih sebagai cerminan besar kecilnya permeabilitas kulit benih dikendalikan oleh senyawa lignin yang ada di dalam kulit benih mengingat keberadaan senyawa lignin sebagai polimer alami dapat ditemukan disetiap sel kulit benih dengan fungsi sebagai penyusun dinding sel. Adanya hubungan yang erat antara kandungan lignin dengan permeabilitas kulit benih maupun dengan banyaknya rembesan isi sel telah terbukti pada benih kedelai (Marwanto, 2003b; Panobianco et al., 2000), namun hal ini belum terbukti pada benih kacang hijau meskipun keduanya sesama benih legum. Menurut mereka terdapat hubungan terbalik antara kandungan lignin dengan permeabilitas kulit benih maupun dengan banyaknya rembesan isi sel. Hubungan yang sama diharapkan juga terjadi pada benih kacang hijau.
Bila hubungan itu benar-benar terjadi pada benih kacang hijau maka patut diduga bahwa semakin tinggi kandungan lignin dalam kulit benih kacang hijau, semakin rendah pula permeabilitas maupun banyaknya rembesan isi selnya.

Penelitian ini bertujuan mempelajari keragaman kandungan lignin kulit benih kacang hijau dan hubungannya dengan permeabilitas, daya hantar listrik (DHL) dan benih keras antar 11 genotipe kacang hijau.

\section{METODE PENELITIAN}

Benih kacang hijau yang digunakan sebagai bahan tanam sebanyak 11 genotipe (Tabel 1). Kesebelas genotipe ini ditanam di lahan percobaan Fakultas Pertanian Universitas Bengkulu pada bulan Pebruari 2002. Selama penanaman, lahan diberi pupuk $\mathrm{N}$ berbentuk urea sebanyak $100 \mathrm{~kg}$ $\mathrm{ha}^{-1}$, P berbentuk TSP sebanyak $80 \mathrm{~kg} \mathrm{ha}^{-1}, \mathrm{~K}$ berbentuk $\mathrm{KCl}$ sebanyak $80 \mathrm{~kg} \mathrm{ha}^{-1}$ dan pupuk kandang sebanyak 3 ton ha ${ }^{-1}$. Pemanenan benih kacang hijau dari sebelas genotipe dilakukan pada saat benih mencapai fase R8 (pada saat 95\% polongnya telah berwarna hitam kecoklatan) secara manual. Polong selanjutnya dikeringangin kan dalam pengering (drier) pada $35{ }^{\circ} \mathrm{C}$ selama 48 jam. Setelah selesai dikeringanginkan, polong dikupas secara manual dan benihnya dipakai sebagai bahan untuk pengukuran kandungan lignin, permeabilitas, daya hantar listrik sebagai pengukur jumlah rembesan isi sel dan benih keras. Penelitian ini ditata dalam Rancangan Acak Kelompok Lengkap dan diulang tiga kali dengan genotipe sebagai faktor tunggalnya. Rerata antar perlakuan dibandingkan dengan Duncan Multiple Range Test (DMRT) pada taraf 5\%. Analisis regresi antara kandungan lignin kulit benih dengan permeabilitas, DHL dan benih keras juga dilakukan (Steel and Torrie, 1981).

Kandungan acid detergent lignin (ADL) kulit benih dari masing-masing genotipe dianalisa dengan metode Van Soest and Wine (1968). Sampel kulit benih dari masing-masing genotipe sebanyak $1.0 \mathrm{~g}$ diekstraksi dengan eter untuk menghilangkan lemaknya, selanjutnya dengan air untuk menghilangkan karbohidrat terlarutnya, dan 
berikutnya dengan asam sulfat encer untuk menghilangkan proteinnya. Setelah ketiga senyawa dalam kulit benih tersebut telah diekstraksi, maka kandungan ligninnya dihitung dengan cara mengoksidasi kulit benih yang telah diekstraksi tersebut dengan larutan potasium permanganat.

Permeabilitas benih ditentukan dengan metode Horlings et al. (1991). Sebanyak 10 benih dengan kadar air $10 \%$ dan diketahui beratnya direndam dalam $2.5 \mathrm{~mL}$ air distilasi selama dua jam pada suhu kamar. Setelah perendaman selesai, air yang ada di permukaan benih dihilangkan dengan kertas saring dan benih ditimbang. Permeabilitas benih dihitung berdasarkan jumlah air yang diserapnya per satuan waktu.

Daya hantar listrik (DHL) sebagai cerminan jumlah elektrolit yang keluar dari dalam benih sewaktu benih berada dalam media basah diukur dengan electric conductivity meter (Cole Parmer, Chicago, Illinois). Sebanyak 25 benih yang telah diketahui beratnya direndam dalam $25 \mathrm{~mL}$ air distilasi selama 24 jam pada suhu kamar. Air rendamannya diukur daya hantar listriknya.

Persen benih keras ditentukan dengan cara menempatkan sebanyak 25 benih kacang hijau di atas dua lapis kertas saring Whatman berbentuk bulat yang dibasahi dengan air distilasi. Kertas saring tersebut diletakkan di dalam cawan petri berdiameter $25 \mathrm{~cm}$. Setelah direndam selama 24 jam benih dilihat keadaannya. Benih dianggap keras bila tidak ada tanda-tanda benih tersebut menyerab air dengan ciri kulit benihnya tetap licin, tidak mengkerut, tidak lunak dan tidak membengkak.

\section{HASIL DAN PEMBAHASAN}

Hasil sidik ragam menunjukkan bahwa dari sisi kandungan lignin kulit benihnya terdapat perbedaan yang nyata antar genotipe. Hal ini menunjukkan bahwa kulit benih antar genotipe kacang hijau memiliki kandungan senyawa lignin yang berbeda jumlahnya dan perbedaan kandungan lignin tersebut tercermin pada nilai \% ADL nya (acid detergent lignin). Perbedaan kandungan lignin dalam kulit benih juga ditemukan pada benih legum lainnya, yaitu pada benih kedelai (Marwanto, 2003b; Panobianco et al., 2000). Dari sebelas genotipe kacang hijau yang diuji, genotipe Bhakti, Merak dan Gelatik tergolong genotipe yang memiliki kandungan lignin tinggi, yaitu sebesar $0.060-0.070 \%$ (Tabel 1). Kandungan lignin yang tinggi ini secara genetis merupakan sifat yang menguntungkan terutama untuk meningkatkan mutu benih. Pada benih kedelai misalnya, kandungan lignin yang tinggi meningkatkan ketahanannya terhadap kerusakan mekanis (Alvarez et al., 1997), sedang pada benih kacang hijau pengaruhnya belum diketahui sehingga diperlukan penelitian lebih lanjut.

Tabel 1. Pengaruh genotipe kacang hijau terhadap kandungan lignin kulit benih (ADL), permeabilitas (P), daya hantar listrik (DHL).dan benih keras.

\begin{tabular}{|c|c|c|c|c|}
\hline Genotipe & $\operatorname{ADL}^{x}(\%)$ & $\mathrm{P}^{\mathrm{x}}\left(\mathrm{g} \mathrm{g}^{-1} \mathrm{jam}^{-1}\right)$ & 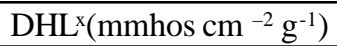 & Benih keras $^{\mathrm{x}}(\%)$ \\
\hline Bhakti & $0.070 \mathrm{a}$ & $0.008 \mathrm{e}$ & $0.198 \mathrm{e}$ & $49.3 \mathrm{a}$ \\
\hline Merak & $0.070 \mathrm{a}$ & $0.043 \mathrm{c}$ & $0.258 \mathrm{de}$ & $20.0 \mathrm{c}$ \\
\hline Gelatik & $0.062 \mathrm{ab}$ & $0.029 \mathrm{~d}$ & $0.189 \mathrm{e}$ & $20.0 \mathrm{c}$ \\
\hline Betet & $0.054 \mathrm{bc}$ & $0.071 \mathrm{a}$ & $0.190 \mathrm{e}$ & $30.0 \mathrm{~b}$ \\
\hline Parkit & $0.050 \mathrm{~cd}$ & $0.039 \mathrm{c}$ & $0.258 \mathrm{de}$ & $32.0 \mathrm{~b}$ \\
\hline IPB.M/97-13-60 & $0.042 \mathrm{de}$ & $0.056 \mathrm{~b}$ & $0.333 \mathrm{~d}$ & $24.0 \mathrm{bc}$ \\
\hline Walet & $0.034 \mathrm{e}$ & $0.065 \mathrm{ab}$ & $0.496 \mathrm{c}$ & $24.0 \mathrm{bc}$ \\
\hline PSJ-BH-5-91 & $0.024 \mathrm{f}$ & $0.063 \mathrm{ab}$ & $0.419 \mathrm{c}$ & $19.3 \mathrm{~cd}$ \\
\hline VC-3012-B & $0.016 \mathrm{fg}$ & $0.068 \mathrm{a}$ & $0.660 \mathrm{~b}$ & $14.0 \mathrm{~d}$ \\
\hline Kenari & $0.010 \mathrm{gh}$ & $0.047 \mathrm{bc}$ & $0.718 \mathrm{ab}$ & $16.0 \mathrm{~cd}$ \\
\hline Vr.1686-3-8-B & $0.007 \mathrm{~h}$ & $0.042 \mathrm{c}$ & $0.796 \mathrm{a}$ & $4.0 \mathrm{e}$ \\
\hline
\end{tabular}

: Angka-angka sekolom yang sehuruf berbeda tidak nyata dengan DMRT pada taraf $5 \%$. 
Hasil sidik ragam terhadap permeabilitas benih menunjukkan bahwa terdapat perbedaan yang nyata antar genotipe. Hal ini berarti bahwa benih dari masing-masing genotipe memiliki kemampuan menyerap air (moisture) yang berbeda dan besarnya kemampuan ini tergantung pada nilai permeabilitasnya. Semakin kecil permeabilitasnya, semakin sedikit air yang dapat diserab oleh benih kacang hijau, ataupun sebaliknya. Menurut Callero et al. (1981), secara fisik jumlah pori (pore) pada kulit benih berperan sebagai faktor penentunya. Lebih lanjut mereka jelaskan bahwa semakin banyak pori tersebut, semakin besar permeabilitasnya ataupun sebaliknya. Perbedaan permeabilitas kulit benih juga dinyatakan oleh Marwanto (2003b); Horlings et al. (1991) pada benih kedelai. Dari sebelas genotipe yang diuji, genotipe Bhakti memiliki permeabilitas terendah sebesar $0.008 \mathrm{~g} \mathrm{~g}^{1}$ jam $^{-1}$.diikuti oleh Gelatik sebesar $0.029 \mathrm{~g} \mathrm{~g}^{-1}$ jam $^{-1}$ (Tabel 1). Permeabilitas kulit yang rendah ini secara genetis merupakan sifat yang menguntung kan terutama untuk meningkatkan mutu benih. Pada benih kedelai misalnya, permeabilitas kulit yang rendah meningkatkan ketahanannya terhadap deraan cuaca (Marwanto, 2003c; Dassou and Kueneman, 1984), sedang pada benih kacang hijau pengaruhnya belum diketahui sehingga diperlukan penelitian lebih lanjut. Bila dikaitkan dengan kandungan lignin dalam kulit benihnya, terdapat hubungan yang erat dan bersifat kuadratik $\left(r=0.75^{*}\right)$ antara kandungan lignin dengan permeabilitasnya dengan persamaan nya $\mathrm{y}=0.04+1.77 \mathrm{X}-27.70 \mathrm{X}^{2}($ Gambar 1$)$. Dengan sifat hubungan ini berarti bahwa setelah sampai pada kandungan lignin tertentu (kira-kira $0.03 \%$ ) semakin banyak kandungan lignin dalam kulit benih suatu genotipe, semakin rendah permeabilitasnya ataupun sebaliknya. Hubungan yang bersifat negatif antar keduanya dilaporkan oleh Marwanto (2003a) pada benih kedelai.

Hasil sidik ragam terhadap DHL menunjukkan bahwa terdapat perbedaan yang nyata antar genotipe. Nilai DHL tersebut beragam antar genotipe dan keragaman ini disebabkan oleh perbedaan kandungan lignin dalam kulit benihnya. Genotipe dengan kandungan lignin tinggi seperti Bhakti, Merak, Gelatik, Betet dan Parkit memiliki nilai DHL berkisar antara $0.189-0.258$ mmho $\mathrm{cm}^{-2} \mathrm{~g}^{-1}$ dan lebih rendah daripada genotipe dengan kandungan lignin rendah (Tabel 1). Perbedaan DHL juga dilaporkan oleh Marwanto (2003a) dan Panobianco et al. (2000) pada genotipe kedelai. Bila dikaitkan dengan kandungan lignin dalam kulit benihnya, terdapat hubungan yang erat dan negatif $\left(\mathrm{r}=-0.93^{*}\right)$ antara kandungan lignin dan DHL dengan persamaannya y $=0.75-9.91 \mathrm{X}$ (Gambar 2). Hal ini berarti bahwa semakin tinggi kandungan lignin dalam kulit benih, semakin rendah nilai DHLnya ataupun sebaliknya. Sifat hubungan yang sama dinyatakan pula oleh Marwanto (2003a) dan Panobianco et al. (2000) pada benih kedelai.

Menurut McDougall et al. (1996) hubungan keduanya ini terjadi karena lignin berperan dalam menentukan kapasitas dan kecepatan penyerapan air melalui kulit benihnya sehingga pada akhirnya juga berpengaruh terhadap jumlah rembesan elektrolit yang keluar dari dalam benih selama benih tersebut berada dalam air.

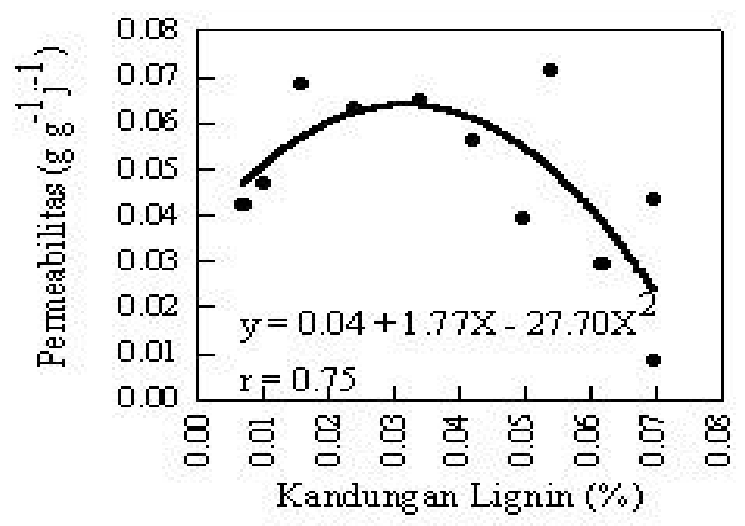

Gambar 1. Hubungan antara permeabilitas dan kandungan lignin kulit benih untuk kesebelas genotipe kacang hijau 


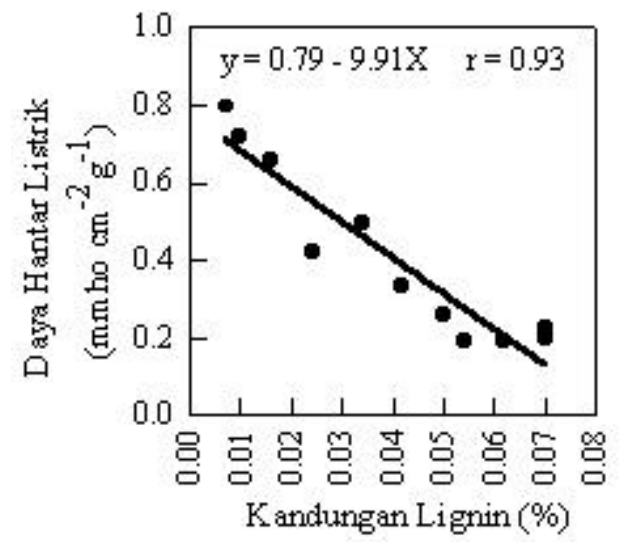

Gambar 2. Hubungan antara daya hantar listrik dan kandungan lignin kulit benih untuk kesebelas genotipe kacang hijau

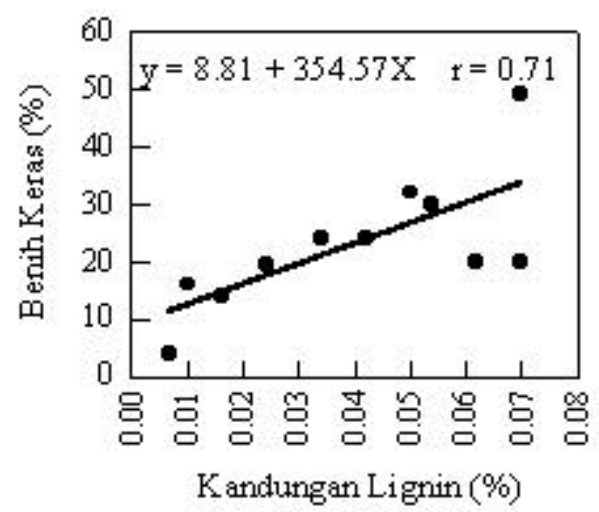

Gambar 3. Hubungan antara benih keras dan kandungan lignin kulit benih untuk kesebelas genotipe kacang hijau

Hasil sidik ragam terhadap benih keras menunjukkan bahwa terdapat perbedaan yang nyata antar genotipe. Hal ini berarti bahwa persen benih keras beragam antar genotipe dan tinggi rendahnya persen benih keras tersebut tergantung pada genotipe masing-masing. Persen benih keras tertinggi didapatkan pada genotipe Bhakti sebesar 49.0\% diikuti oleh genotipe Parkit sebesar 32.0\% dan genotipe Betet sebesar 30\%. Persen benih keras terendah didapatkan pada genotipe Vr.16863-8-B sebesar 4.0\%. Fenomena benih keras pada benih kacang hijau merupakan hal yang biasa seperti halnya terjadi pada benih legum lainnya seperti benih kedelai (Chuntirapongsa, 1992; Dassou and Kueneman, 1984; Hartwig and Potts, 1987). Sifat benih keras ini secara genetis merupakan sifat yang menguntungkan terutama untuk meningkatkan mutu benihnya. Pada benih kedelai misalnya, genotipe yang memiliki sifat benih keras mampu mempertahankan mutu benihnya tetap tinggi meskipun terdera oleh kelembaban dan suhu yang tinggi selama di lapang (Hartwig and Potts, 1987; Dassou and Kueneman, 1984) ataupun di penyimpanan (Chuntirapongsa, 1992). Sedang pada benih kacang hijau pengaruhnya belum diketahui secara jelas sehingga diperlukan penelitian lebih lanjut. Bila dikaitkan dengan kandungan lignin dalam kulit benihnya, terdapat hubungan yang erat dan positif $\left(\mathrm{r}=0.71^{*}\right)$ antara kandungan lignin dengan persen benih keras dengan persamaannya $\mathrm{y}=8.81+354.57 \mathrm{X}$ (Gambar 3). Hal ini berarti bahwa semakin tinggi kandungan lignin dalam kulit benih, semakin tinggi pula persen benih kerasnya ataupun sebaliknya. Menurut McDougall et al. (1996) hubungan keduanya ini terjadi karena lignin berperan dalam menentukan kapasitas dan kecepatan penyerapan air melalui kulit benihnya.

\section{KESIMPULAN}

Genotipe kacang hijau memiliki kandungan lignin kulit benih yang berbeda dan perbedaan ini menyebabkan keragaman sifat khusus kulit benihnya seperti permeabilitas, DHL maupun benih kerasnya. Tinggi rendahnya permeabilitas, DHL dan benih keras sangat dipengaruhi oleh kandungan lignin kulit benih.

\section{DAFTAR PUSTAKA}

Alvares, P.J.C., F.C. Krzyzanowski, J.M.G. Mandarino and J.B. Franca Neto. 1997. Relationship between soybean seed coat lignin content and resistance to mechanical damage. Seed Sci. Tech. 25:209-214.

Chuntirapongsa, S. 1992. Effects of seed coat color on storability of soybean seeds. Dissertation (Ph.D.). Miss. State Univ., Miss. State, MS.

Calero, S.H., S.H. West and K. Hinson. 1981. Water absorption of soybean seeds and associated causal factor. Crop Sci. 21:926933. 
Dassou, S. and E.A. Kueneman. 1984. Screening methodology for resistance to field weathering of soybean seed. Crop Sci. 24:774-779.

Halloin, J.M. 1983. Deterioration resistance mechanisms in seeds. Phytopathology 73:335340.

Hartwig, E.E and H.C. Potts. 1987. Development and evaluation of impermeable seed coat for preserving soybean seed quality. Crop Sci. 27:506-508.

Horlings, G.P., E.E. Gamble and S. Shanmugasundaram. 1991. The influence of seed size and seed coat characteristics on seed quality of soybean in the tropics: Field weathering. Seed Sci. Tech. 19:665-685.

Keigley, P.J. and R.E. Mullen 1986. Changes in soybean seed quality from high temperature during seed fill and maturation. Crop Sci. 26:1212-1216.

Lewis, N.G. and E. Yamamoto. 1990. Lignin: occurrence, biogenesis and biodegradation. Ann. Rev. Plant Physiol, Plant Mol. Biol. 41:455-496.

Kuo, W.H.J. 1989. Delayed-permeability of soybean seed: characteristic and screening methodology. Seed Sci. Tech. 13:322-325.

Marwanto. 2003a. Keragaman resistensi beberapa genotipe benih kedelai terhadap deraan cuaca: I. Pengaruh metode penapisan. J. Akta Agrosia 6: 18 - 22.
Marwanto. 2003b. Hubungan antara kandungan lignin kulit benih dengan permeabilitas dan daya hantar listrik rendaman benih kedelai. J. Akta Agrosia. 6: 51 - 54 .

Marwanto. 2003c. Genotypic differences in soybean seeds for resistance to field deterioration: II. The role of seed coat characteristics. JIPI 5: $58-63$.

McDougall, G.J., I.M. Morrison, D. Stewart and J.R. Hillman. 1996. Plant cell walls as dietary fiber: range, structure, processing and function. J. Sci. Food and Agric. 70:133-150.

Panobianco, D., R.D. Vieira, F.C. Krzyzanowski, and J.B. Franca Neto. 1999. Electrical conductivity of soybean seeds and correlation with seed coat lignin content. Seed Sci. Tech 27: 945-949.

Steel, R.G.D. and J.H. Torrie. 1981. Principles and Procedures of Statistics: A Biometrical Approach. $2^{\text {nd. }}$ ed. McGraw-Hill International Book Company, Singapore. 633p.

Tavares, D.Q., M.A.C. Miranda, C.Y. Umino and G.M. Dias. 1987. Structural characteristics of seed coat of permeable and impermeable of seeds of soybeans breeding line. Revista braseleira de Botanica. 10:147-153.

Van Soest, P.J. and R.H. Wine. 1968. Determination of lignin and cellulose in acid detergent fiber with permanganate. J. Assoc. Off. Agric. Chem. 51:780-785. 